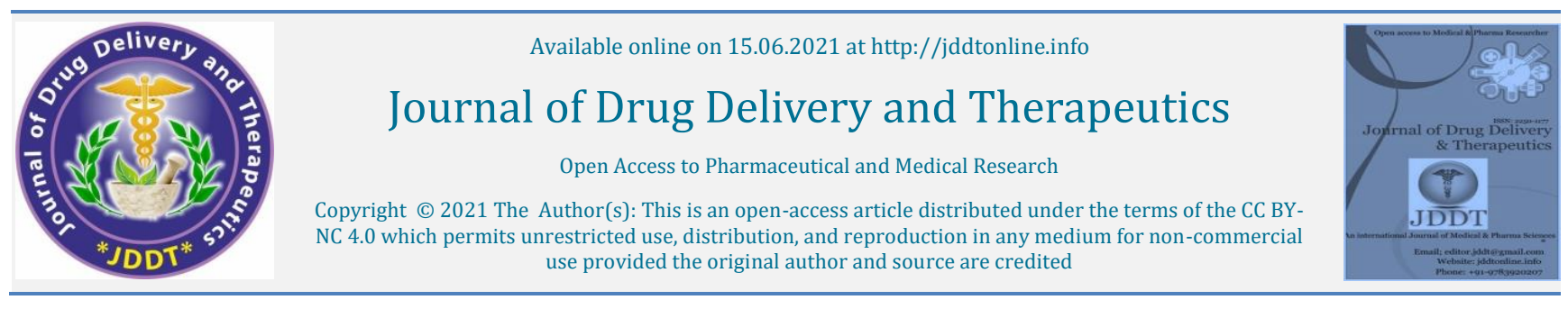

\title{
Open Access Full Text Article \\ Clinical features and management strategies of Meningitis in adult patients: A hospital based study from Kuwait
}

\author{
${ }^{1,2}$ Al-Shammri Suhail*, ${ }^{2}$ Chattopadhyay Arpita, ${ }^{1}$ Chadha Geeti, ${ }^{1,3}$ Zeyada Ahmed S, ${ }^{4,5}$ Al Shaifan Faisal, \\ ${ }^{1}$ Abu Qoora Amr, ${ }^{5}$ Rotimi Vincent \\ ${ }^{1}$ Neurology Unit, Mubarak Al Kabeer Hospital, Ministry of Health, Jabriya, Kuwait \\ ${ }^{2}$ Division of Neurology, Department of Medicine, Faculty of Medicine, Jabriya, Kuwait University, Kuwait, Postal Address-P.O. Box 24923, Safat \\ 13110, Kuwait
}

${ }^{3}$ Dar Al Shifa Hospital, Kuwait

${ }^{4}$ Kuwait Cancer Control Center, Al Sabah Medical District, Kuwait

${ }^{5}$ Department of Microbiology, Department of Medicine, Faculty of Medicine, Jabriya, Kuwait University, Kuwait

\begin{tabular}{ll}
\hline Article Info: & \\
\hline & Article History: \\
& $\begin{array}{l}\text { Reveived 13 April 2021 } \\
\text { Accepted 03 June 2021 } \\
\text { Available online 15 June 2021 }\end{array}$ \\
\hline
\end{tabular}

\section{Cite this article as:}

Al-Shammri S, Chattopadhyay A, Chadha G, Zeyada AS, Al Shaifan F, Abu Qoora A, Rotimi V, Clinical features and management strategies of Meningitis in adult patients: A hospital based study from Kuwait Journal of Drug Delivery and Therapeutics. 2021; 11(3-S):53-60

DOI: http://dx.doi.org/10.22270/jddt.v11i3-S.4893

\section{*Address for Correspondence:}

Suhail Al-Shammri, Faculty of Medicine, Jabriya, Kuwait University, Kuwait, Postal Address- P.O. Box 24923, Safat 13110, Kuwait.

\section{Abstract}

Introduction: High mortality rate of meningitis has been reported in Kuwait, however, limited data is available describing this disease in adult patients. With this background, we conducted a prospective study on patients admitted with meningitis, with an objective to describe the risk factors, clinical presentation, disease course and outcome; focus given on diagnostic problems and consequent management difficulties.

Methods: Our team diagnosed, managed and documented hospital records of patients $(\mathrm{n}=44)$ admitted with suspected meningitis at a referral hospital during 2010-12. Detailed information was collected regarding clinical presentation, CSF analysis, treatment, hospital course and outcome as per Glasgow Outcome Scale (GOS). Results: Bacterial, viral, and tuberculosis (TB) meningitis were seen in $22.8 \%, 52.3 \%$, and $15.9 \%$ of patients. Clinical features of our cohort were consistent with available literature. Positive identification of organism by culture, gram stain, or antigen test was possible in only 6 patients i.e. Streptococcus pneumonae-( $(\mathrm{n}=3)$, Streptococcus agalactiae- $(n=2)$, Neisseria meningitides$(\mathrm{n}=1)$. CSF polymerase chain reaction was detected positive for Enterovirus RNA, and Herpes simplex virus DNA for one patient each. Empirical antimicrobial treatment directed against common causative organisms was the mainstay of management of bacterial meningitis. Viral meningitis was managed symptomatically. TB meningitis patients were administered anti-tubercular treatment. As per GOS, 38(85.4\%) patients recovered with no neurological deficit. Six patients recovered with mild to moderate deficit. Conclusion: Low positive culture rates and inability to identify pathogens have been a diagnostic challenge faced by our team. Strong clinical suspicion, early empiric antibiotic and dexamethasone therapy perhaps contributed to very good recovery in our study.

\section{INTRODUCTION:}

Meningitis is most common cerebrospinal infection affecting all age groups with a worldwide prevalence and it is associated with sufficient morbidity and mortality in different regions of the world ${ }^{1-3}$. Despite progress being made in treating meningitis, mortality rates continue to be high, ranging between $2 \%$ and $30 \%$ globally ${ }^{4-6}$. Apart from epidemics, at least 1.2 million cases of meningitis are estimated to occur with estimated annual deaths of 170,000 7,8. In early $21^{\text {st }}$ century meningitis caused an estimated 173,000 deaths worldwide, mostly among children from developing world 9. Occurrence and microbial etiology of meningitis varies according to geographic region, with degrees of endemicity. Most common causes of meningitis are viral infections that usually results in better outcome. However, bacterial meningitis infections are serious, and may result in death or brain damage, even if treated. In middle and low-income countries, acute bacterial meningitis remains the fourth leading cause of disability 10 . Prevalence of bacterial meningitis in these countries is higher compared to developed countries. Bacterial meningitis is caused by a number of organisms, but beyond neonatal period, over $90 \%$ of infections are caused by Streptococcus pneumonae (S. pneumoniae), Haemophilus influenzae (H. influenzae) and Neisseria meningitidis ( $N$. meningitidis) ${ }^{10}$. Over last two decades, however, the causative agents of meningitis have changed with introduction of different highly effective vaccines ${ }^{11}$. $H$. influenzae type $\mathrm{b}(\mathrm{Hib})$ used to be a common 
cause of bacterial meningitis worldwide before the Hib vaccines ${ }^{12}$. However, more recently, S. pneumoniae and $N$. meningitidis have been identified as major organisms causing meningitis. In countries with high HIV prevalence, Cryptococcus neoformans ( $C$ neoformans) may also be significant.

Available meningitis epidemiology data from the Ministry of Health of Kuwait reveals 86 cases of meningococcal disease between 1997-2003 and 71 cases from 2004-2009 13. Overall mortality rate from meningitis in Kuwait is high; for the period 1997-2003 it was 9.3\% and in 2004-2009(6 deaths in 71 cases) mortality was $8.4 \%$. In, 1998 itself mortality rate of meningococcal disease was 33.3\%, declining to 0 in 2003 and again raised to $12.5 \%$ in 2009 (8 deaths in 86 cases) ${ }^{13}$. All children are routinely vaccinated in Kuwait against $H$. influenzae type b since 1996. In addition, a polysaccharide meningococcal vaccine (A, C, Y, and W135) is administered routinely to all children at age of 2 years. In August 2006, a seven-valent pneumococcal conjugate vaccine has been introduced into immunization program. Despite of elaborate vaccination program, high mortality rate in meningitis prevails in Kuwait. Though, Kuwait is an oil rich country with high per capita income, population of Kuwait is comprised of Kuwaiti nationals and foreigners living in Kuwait for employment purposes. Many foreigners are contact laborers from different countries of Gulf, African, Asia and South East Asian region. Some of these countries belongs to endemic meningitis region. This may contribute to higher mortality rate of meningitis in Kuwait. Epidemiological pattern of bacterial and aseptic meningitis in infants has been studied in Kuwait 14-16, but there are almost no data available for adults and young adults. Information on pathogens contributing to meningitis in hospital based studies is very limited as well. Hereby, more hospital based studies for both adults and children are further necessary to improve clinical management, therapeutic decisions and for designing preventive strategies. With this back ground we performed a prospective study of patients admitted with meningitis in a tertiary referral center and teaching hospital in Kuwait, during calendar year of 2010-12.

Objectives of our study was to describe the clinical presentation and characterictics of meningitis in adult patients and to document the demographic profile, risk factors, seasonal pattern, laboratory features, causative organisms and outcome with a focus on diagnostic problems and consequent management difficulties. This study is expected to contribute in better understanding and management of meningitis in a clinical setup with limited facilities and to help clinician for achieving good outcome even when identification of causal organism is not possible .

\section{MATERIALS AND METHODS:}

Subjects: In this prospective study, we recruited 44 patients (age $\geq 15$ years) with suspected meningitis. These patients were admitted in Mubarak Al Kabeer Hospital in the calendar year 2010-12 (January 1, 2010 - December 31, 2012). This Hospital is a tertiary referral hospital situated at Hawalli governorate with a catchment area which includes 8 cities (Hawali, Jabriya, Mishref, Byan, Salmiya, Salwa, Rumethiya and Sabah Al Salem) of Kuwait, and covers almost half of total population of Kuwait ${ }^{17}$.

Ethical statement: This study has been carried out in accordance with The Code of Ethics of the World Medical Association (Declaration of Helsinki) for experiments involving humans. Each subject has signed an informed consent.
Data collection: We collected detailed information about demographic data of each subjects, including age, sex, and season of onset of meningitis. Seasons were defined as winter (December-6 to February-15), followed by spring (February-16 to May-2) and the summer (May-21 to November-4) ${ }^{18}$. Moreover, history of exposure to sick contacts, travel, sexual and substance abuse history were collected. We also documented their past medical history and emphasis was given on history of any recent or concomitant respiratory or gastrointestinal infection. A team of experienced neurologists examined patients for clinical presentation and diagnosis was done following criteria mentioned below. CSF was collected and sent for laboratory analysis including Gram stain, culture, and cell count with differential count, estimation of protein and glucose level. Detailed data was documented on their hospital course, treatment and outcome as per GOS at discharge.

Diagnostic criteria of meningitis: Confirmed diagnosis of meningitis was made on the basis of clinical presentation and laboratory results ${ }^{19}$, 20. Patients were evaluated for typical presenting symptoms of meningitis namely fever, nuchal rigidity, headache, altered mental status and meningeal signs include Kernig's sign and Brudzinski's neck sign 19, 20. Patients with strong clinical suspicion and having at least 2 of the 4 symptoms: fever, neck stiffness, headache, or altered mental status (GOS $<14$ ) were included in the study ${ }^{21}$.

Bacterial meningitis was diagnosed following clinical presentation, like acute onset of severe classical symptoms developed over hours to days, insensitive but highly specific Kerning's and Brudzinski's signs and positive CSF microbiology including positive bacterial culture and gram stain 22, 23. Moreover, a cloudy appearance of CSF, presence of neutrophilic pleocytosis, decreased sugar, elevated protein and lactate levels in CSF indicated bacterial meningitis.

Presence of milder symptoms, onset at young age, benign clinical course indicated presence of viral meningitis or aseptic meningitis. Special emphasis given on presence of fever and jolt accentuation of headache, as these symptoms has been reported as the most sensitive sign 24,25 . Altered mental status, focal neurologic signs and seizures were uncommon in viral meningitis; if present, those prompted for consideration of viral encephalitis or bacterial meningitis ${ }^{26-}$ 28. Patients of aseptic meningitis were closely monitored as it can cause significant morbidity and mortality in individuals having deficient humoral immunity ${ }^{29}$. Lymphocytic pleocytosis, normal or slightly reduced sugar, and normal lactate level in CSF indicated viral meningitis. CSF was also examined to detect viral titers and to identify viral DNA and/or RNA by commercially available PCR kits for Herpes simplex virus (HSV), enteroviruses etc. However, we did not do viral culture and serology for identification of the virus.

Tuberculous (TB) meningitis was identified by subacute disease courses, positive Ziehl Neelsen strain, positive mycobacterial culture and positive PCR for M. tuberculosis DNA ${ }^{30}$. In case of negative culture and stains, we relied on PCR (sensitivity $85 \%$ to $95 \%$ ) to diagnose, but a negative PCR does not exclude, tuberculous meningitis. Presence of high CSF protein and lactate, very low sugar, lymphocytic pleocytosis also indicated TB meningitis.

CSF processing and bacterial or fungal culture: All CSF samples were processed at the microbiology laboratory of Mubarak Al Kabeer hospital using standard microbiology techniques. Laboratory analysis included WBC estimation and differential counts, direct wet mount, Gram staining and India ink staining of the CSF deposits and culturing on chocolate agar, blood agar (Oxoid, Basingstoke Reading, UK) and Sabouraud agar (Oxoid). All inoculated culture plates for 
bacterial isolation were incubated at $37^{\circ} \mathrm{C}$ for $24-48$ hours in $5 \%$ carbon dioxide, while incubation of Sabouraud was at room temperature, respectively. Representative colonies were identified by standard microbiological techniques adapted from the WHO laboratory manual for diagnosing bacterial meningitis $22 . N$. meningitidis species were identified by Gram stain, Oxidase test and colony morphology (VITEK-2 (bioMerieux), E. coli (Merck, France); while $H$. influenzae identification was based on requirement for $\mathrm{X}$ and $\mathrm{V}$ growth factors. Optochin sensitivity for confirmation of $S$. pneumoniae was based on a zone size of $14 \mathrm{~mm}$ or more and solubility to $2 \%$ bile salt. Fungal growths on Sabouraud agar were confirmed using India ink and analytical profile index (API) (bioMerieux, France). All other bacteria isolates were identified by VITEK 2. Antimicrobial susceptibility testing was done using VITEK 2 ATS cards (bioMerieux) and $\mathrm{E}$ test (bioMerieux) methods. The antibiotics tested included ampicillin, ampicillin-clavulanic acid, ceftriaxone, chloramphenicol, cefotaxime, cefoxitin, meropenem, amikacin, gentamicin, trimethoprimsulfamethoxazole $(30 \mu \mathrm{g})$ and vancomycin.

Specific diagnostic tests: Positive latex particle agglutination is indicative of bacterial meningitis and rapid latex agglutination tests are available for $H$. influenzae, $S$. pneumoniae, N. meningitides (except Type B), E coli, and Group B Streptococcus (GBS). We did latex particle agglutination test for all the patients; however, these have not been much helpful in antimicrobial management, owing to limitations in sensitivity and specificity. PCR is also reported to be used for rapid detection of S. pneumoniae, $N$. meningitidis, H. influenzae, GBS, and L. monocytogenes ${ }^{23}$; however, we use this technique only in case of viral meningitis suspicion.

Imaging: Head CT was done for all patient included in this study. Magnetic resonance imaging (MRI) was done in those patients, who suffered from seizures or focal neurologic deficits, or display other evidence of increased intracranial pressure. Electroencephalography was done in all patients with suspected viral meningitis.

Patient Management and treatment consideration: In case of suspicion of possible bacterial meningitis, broadspectrum antimicrobial therapy was initiated immediately after lumbar puncture, and continued until initial CSF results and/or PCR results become available to prevent rapid clinical deterioration and a poor outcome. Afterward, subsequent specific antibiotic adjustments were done based on CSF culture and susceptibility testing results. Moreover, Empirical antimicrobial treatment directed against common organisms seen in meningitis was the mainstay of the management for bacterial meningitis patients without positive identification of organism. Dexamethasone therapy is initiated before the first antibiotic dose in our patients if required. This treatment attenuates the inflammatory response in the subarachnoid space and therefore limits cellular damage 31 . However, in adults there is no evidence that dexamethasone therapy before antibiotics is of benefit with pathogens other than $S$ pneumoniae ${ }^{31}$, therefore if $S$ pneumoniae is ruled out as an etiologic agent, dexamethasone therapy was usually discontinued. Patients with bacterial meningitis were admitted or transferred to the intensive care unit for close monitoring. Viral meningitis patients were managed symptomatically. Once, bacterial meningitis and HSV infection have been ruled out, supportive care with pain and fever control is usually the treatment of choice for aseptic meningitis. Aciclovir is the drug of choice if HSV is diagnosed.
Patients diagnosed with TB meningitis were administered anti-tubercular (isoniazid, rifampin, ethambutol, pyrazinamide) treatment.

\section{Supportive care and adjunctive therapies}

Neurologists of our team monitored patients with bacterial meningitis closely for clinical deterioration. Airway support or intubation was considered in patients with an increased respiratory rate, oxygen saturation less than $90 \%$, or partial pressure of oxygen less than $60 \mathrm{~mm} \mathrm{Hg}{ }^{32}$. Hemodynamic monitoring was necessitated to assess response to fluid resuscitation and/or inotropic agents as septic shock may occur. Patients were also monitored for development of syndrome of inappropriate antidiuretic hormone (SIADH) and given intensive fluid resuscitation if required. Protonpump inhibitors were prescribed to decrease the incidence of gastric ulceration as per requirement. Elevated CSF pressure was treated with dexamethasone, use of osmotic diuretics such as mannitol (25\%) or hypertonic saline $(3 \%)$, hyperventilation and elevation of the head of the bed to $30^{\circ}$. Anticonvulsants were prescribed if seizures occur during the clinical course, and electroencephalographic monitoring also performed if required.

\section{RESULTS:}

Forty-four patients (mean age \pm SD: $31.8 \pm 13.8$ ) with suspected meningitis were included in this study. Our study population was comprised of $63.3 \%$ male and $36.4 \%$ female. Most of our patients $(70.5 \%$; $n=31$ ) were aged 21 years or above and $13(29.5 \%)$ were between $15-21$ years of age. Kuwaitis $(38.6 \%, \mathrm{n}=17)$ were the largest ethnic group followed by non-Kuwaiti Arabs (27.3\%,n=12), nationals from Indian subcontinent $(25 \%, \mathrm{n}=11)$, and South Asia and Philippines $(9.1 \%, n=4)$ (Fig-1). Most of the patients $(n=31$, $70.5 \%$ ) were living in governorate of Hawalli; however, only 2 patient $(4.6 \%)$ were referred from areas not belongs to this governorate. A seasonal cluster was seen with 24 (54.5\%) admissions in the winter (December to January) (Fig-2). None of our patients reported any significant sick contacts, travel, substance-abuse or history of homosexuality.

Clinical presentation included fever (90.9\%), unconsciousness (79.5\%); vomiting (72.7\%), headache (70.5\%), unsteadiness (65.9\%); neck stiffness (61.4\%), Seizures (50\%). Papilloedema present in $2(4.5 \%)$ patients. (Fig-3).

\section{Imaging abnormalities:}

Abnormal CT scan was found in $10(18.2 \%)$ patients; however MRI was done with 23 patients and $10(31.8 \%)$ among those had some abnomalities. MRI of 2 patients showed changes suggestive of acute disseminated encephalomyelitis, 2 patients had obstructive hydrocephalus with basal menningial enhancement. Three patients with T.B. meningitis showed nodular enhancing leisions in tentorial areas suggestive of tuberculomas. One patient had leptomeningeal enhancement over the frontal lobe. Two patients showd frontal encephalomalacia.

EEG: EEG showed epileptiform discharges in four patients.

On basis of clinical presentation and laboratory analysis definitive diagnosis of bacterial, viral, and TB meningitis were made in $22.8 \%(\mathrm{~N}=10), 52.3 \%(23)$, and $15.9 \%(7)$ patients, respectively. Definitive diagnosis was not possible for 4 patients, who refused CSF analysis.

CSF analysis revealed significantly higher white cell count and higher level of protein in bacterial than in viral meningitis (both $p<0.01$ ). In CSF analysis we fuond higher 
white cell count in bacterial [median (IQR): 533.50 (2746)] compared to viral [106.94 (100)] meningitis. Bacterial meningitis also had a higher elevation of protein (3886.50 $\mathrm{mg} / \mathrm{dL}, \mathrm{IQR} 4355)$ when compared to viral $(631 \mathrm{mg} / \mathrm{dL}, \mathrm{IQR}$ 537). In bacterial meningitis cases, there was leucocytosis present in the peripheral blood with 6 (60\%) patients showing very high counts $\left(>1610^{9} / \mathrm{L}\right)$. There was a positive correlation between blood and CSF WBC counts in bacterial meningitis (Pearson's $\mathrm{r}=0.33, \mathrm{p}<0.05$ ) but not in viral meningitis (Pearson's $r=0.12, p>0.05$ ). The CSF abnormalities found in different meningitis sub-categories is shown in Table 1.

In suspcted bacterial meningitis positive identification of the organism by culture, gram stain, or antigen test was possible in only 6 i.e. $S$ pneumoniae- $(\mathrm{n}=3), S$. agalactiae- $(\mathrm{n}=2)$, Meningococcus- $(\mathrm{n}=1)$. PCR for virus DNA and/or RNA was done for CSF sample of 25 suspected viral meningitis patients and 1 patient each was detected positive for Enterovirus RNA, and HSV DNA, respectively. On the basis of case history, screening for HIV Ag/Ab was suggested for 4 patients and all found negative for it.

Clinical management was done as per protocol explained in material and method section. Details of prescribed medication is represented in table 2 . All the patients except 2 received third generation Cephalosporin (ceftriaxone) with or without combination of other drugs (Table -2). glycopeptide antibiotics (Vancomycin) was given in combination with ceftriaxone in 15 patients.Though, HSV
DNA was detected in only one patient, aciclovir was prescribed for 34 symptomatic patients (18 viral, 8 bacterial, 6 TB and 2 patients without definite diagnosis) (Table -2). Seven meningitis patients were administered with anti-tubercular treatment (i.e. (isoniazid, rifampin, ethambutol, pyrazinamide) after confirmation of having TB meningitis Most of these patients were started receiving empirical antimicrobial treatment before confirmation of TB meningitis. Ten $(22.7 \%)$ patients received dexamethasone treatment. Among them 4 had TB meningitis, 2 were suffering from aseptic meningitis, 1 was Meningicoccus positive, 2 were diagnosed for septic meningitis, and in 1 patient definitive diagnosis could not achieved. Anti epileptic medication (Phenytoin Sodium) was prestribed to 7 patients (3 bacterial and 4 viral meningitis) those who had seizure. We also prescribe chemoprophylaxis for household close contacts of patients with meningococcal meningitis to prevent further spread of bacterial meningitis.

As per GOS most patients $36(81.8 \%)$ recovered without any neurological deficit. Six patients (13.6\%) recovered with mild to moderate deficit. Among these 6 patients 3 had TB meningitis and treated with anti-tuburcular medication and dexomethasone in addition to emperical antibiotics; 2 were diagnosed for aseptic meningitis and received emperical antibiotics; 1 patient had Streptococcal meningitis and treated with a third generation Cephalosporin and aciclovir. Another patient who was diagnosed with HSV infection was treated with aciclovir, and had severe deficit. Outcome was found to be significanly different in patients having different types of meningitis $(\mathrm{p}<0.05)$. This is possibly due to higher morbidity rate noted in TB patients (Table-3).

Table 1: Cerebro Spinal Fluid (CSF) abnormalities found in patients with different types of meningitis.

\begin{tabular}{|c|c|c|c|c|c|c|c|c|}
\hline \multirow[t]{2}{*}{ Variable } & \multicolumn{2}{|c|}{ Viral meningitis (Gr.A) } & \multicolumn{2}{|c|}{$\begin{array}{c}\text { Bacterial meningitis } \\
(\mathrm{Gr} . \mathrm{B})\end{array}$} & \multicolumn{2}{|c|}{ TB meningitis (Gr.C) } & \multirow{2}{*}{\begin{tabular}{l}
\multicolumn{1}{c}{$\boldsymbol{P a}$} \\
\\
Betwee \\
n Gr.A \\
\& Gr.B
\end{tabular}} & \multirow{2}{*}{$\begin{array}{l}\quad \boldsymbol{P}^{\boldsymbol{b}} \\
\\
\text { Among } \\
\text { Gr. A,B } \\
\text { \& C }\end{array}$} \\
\hline & Mean \pm SD & $\begin{array}{l}\text { Median } \\
\text { (Range) }\end{array}$ & Mean \pm SD & $\begin{array}{l}\text { Median } \\
\text { (Range) }\end{array}$ & $\begin{array}{l}\text { Mean } \pm \\
\text { SD }\end{array}$ & $\begin{array}{l}\text { Median } \\
\text { (Range) }\end{array}$ & & \\
\hline $\begin{array}{l}\text { CSF Sugar } \\
(\mathrm{mmol} / \mathrm{L})\end{array}$ & $4.6 \pm 2.0$ & $\begin{array}{l}3.9 \\
(2.1-10.1)\end{array}$ & $2.5 \pm 1.8$ & $\begin{array}{l}2.8 \\
(0.2-4.9)\end{array}$ & $3.6 \pm 1.3$ & $\begin{array}{l}3.8 \\
(1.3-4.9)\end{array}$ & $<0.01$ & ns \\
\hline $\begin{array}{l}\text { CSF Protein } \\
(\mathrm{mg} / \mathrm{L})\end{array}$ & $\begin{array}{l}611.7 \pm \\
417.6\end{array}$ & $\begin{array}{l}631 \\
(8.2-588)\end{array}$ & $\begin{array}{l}3303.1 \pm \\
2182.2\end{array}$ & $\begin{array}{l}3886.5 \\
(281-6045)\end{array}$ & $\begin{array}{l}1486 \pm \\
656\end{array}$ & $\begin{array}{l}1467 \\
(759-2363)\end{array}$ & $<0.01$ & $<0.01$ \\
\hline CSF Cells & $\begin{array}{l}65.2 \pm \\
106.9\end{array}$ & $9(0-440)$ & $\begin{array}{l}1269.2 \pm \\
1503.6\end{array}$ & $\begin{array}{l}533.5 \\
(10-4063)\end{array}$ & $\begin{array}{l}96.7 \pm \\
44.8\end{array}$ & $\begin{array}{l}96 \\
(7-155)\end{array}$ & $<0.01$ & $<0.01$ \\
\hline $\begin{array}{l}\text { CSF } \\
\text { Lymphocytes } \\
(\%)\end{array}$ & $43.5 \pm 41$ & $\begin{array}{l}42.5 \\
(0-96)\end{array}$ & $29.3 \pm 18$ & $\begin{array}{l}24 \\
(10-55)\end{array}$ & $\begin{array}{l}78.4 \pm \\
34.7\end{array}$ & $\begin{array}{l}92 \\
(0-95)\end{array}$ & ns & $<0.05$ \\
\hline $\begin{array}{l}\text { CSF } \\
\text { Polymorphs } \\
(\%)\end{array}$ & $17.5 \pm 23.2$ & $8.5(0-80)$ & $71.2 \pm 17.4$ & $\begin{array}{l}76 \\
(45-90)\end{array}$ & $8.3 \pm 3.5$ & $8(5-15)$ & $<0.01$ & $<0.01$ \\
\hline $\begin{array}{l}\text { CSF lactate } \\
(\mathrm{mmol} / \mathrm{L})\end{array}$ & $2.7 \pm 2$ & $2(1.2-9.1)$ & $9 \pm 6.6$ & $\begin{array}{l}9.1 \\
(1.2-15.5)\end{array}$ & $5.1 \pm 1.7$ & $5.3(1.9-7)$ & $<0.05$ & $<0.05$ \\
\hline
\end{tabular}

Comparative account of levels of different CSF parameters in bacterial, viral and tuberculosis meningitis. $p^{\text {a }}$ values were generated using MannWhitney U test. $p^{\mathrm{b}}$ values were generated using Kruskal Wallis test. 
Table 2: Details of Medications

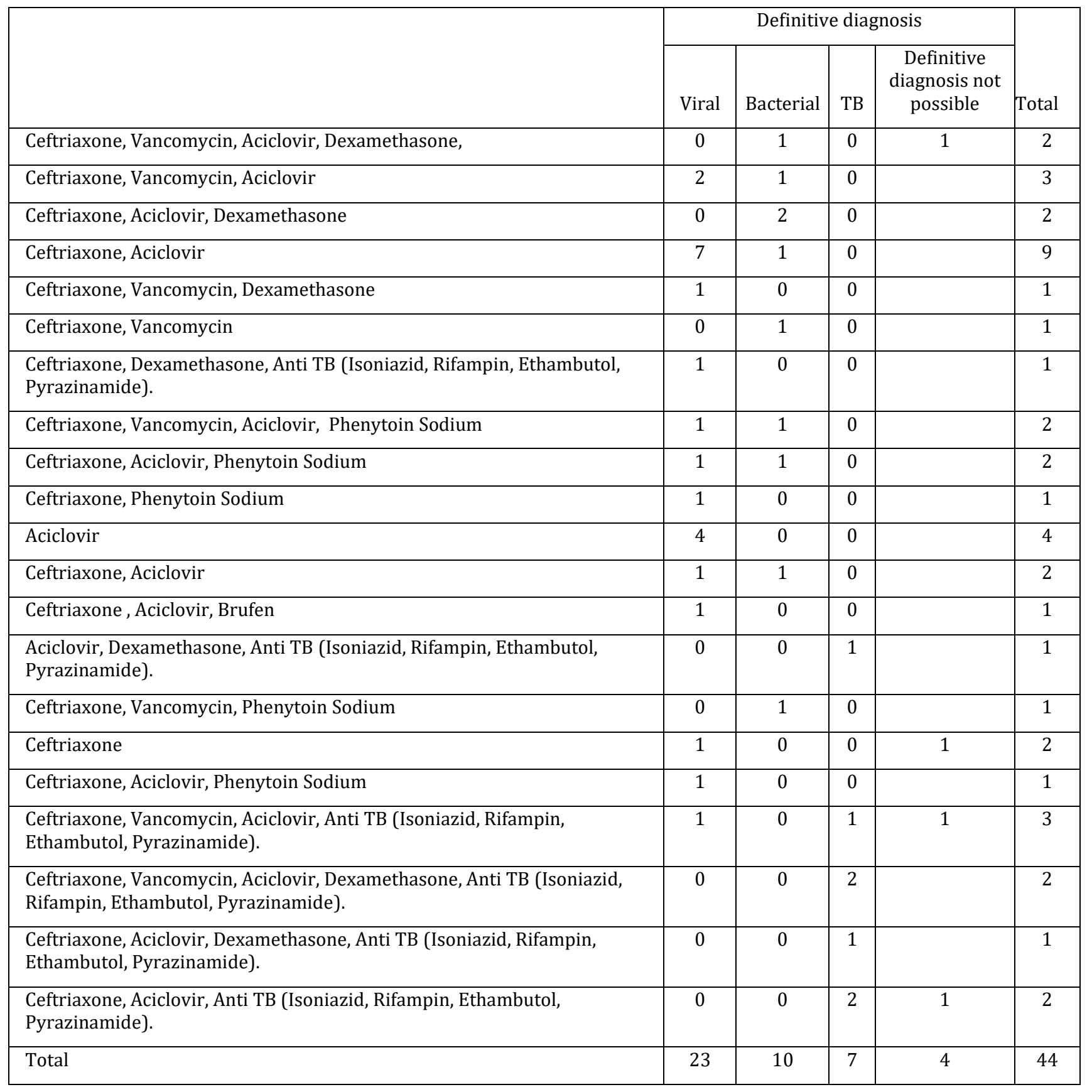

Table 3: Outcome of patients diagnosed for different meningitis as per Galsgow Outcome Scale

\begin{tabular}{|l|l|l|l|l|}
\hline Type of Meningitis (n=44) & Severe deficit & Moderate deficit & Complete recovery & $p$ \\
\hline Viral meningitis (n=23) & $1(4.36 \%)$ & $2(8.69 \%)$ & $20(86.95 \%)$ & 0.048 \\
\hline Bacterial meningitis (n=10) & 0 & $1(10 \%)$ & $9(90 \%)$ \\
\hline TB meningitis (n=7) & 0 & $3(42.86 \%)$ & $4(57.14 \%)$ \\
\hline Differential diagnosis not possible (n=4) & 0 & 0 & $4(100 \%)$ \\
\hline Total & 1 & 6 & 36 & \\
\hline
\end{tabular}

$p$ value was generated using Chi-square test. 
Figure 1: Ethnicity of study cohort

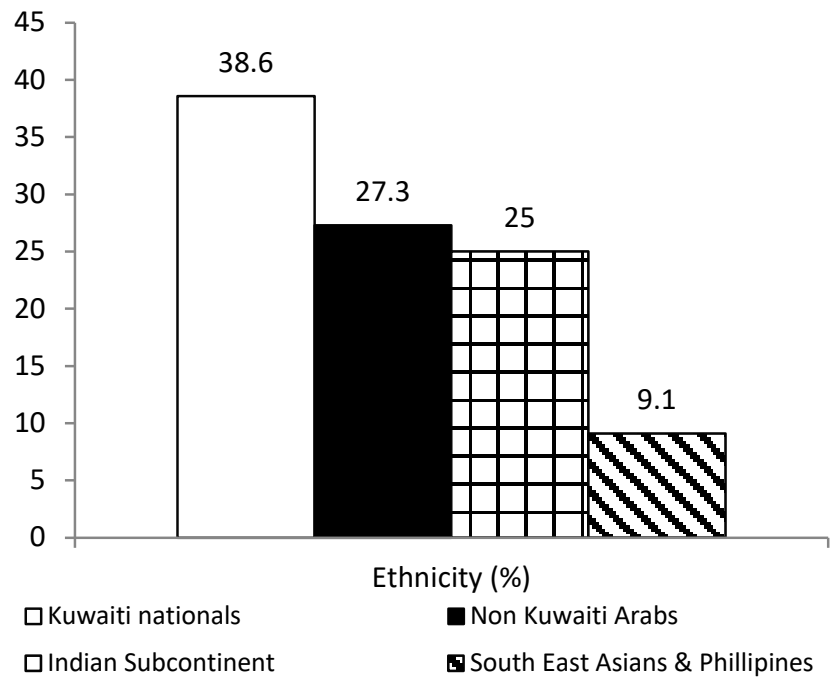

Frequecny of patients belongs to different ethnic group.
Figure 2: Seasonal Variatoion in Meningitis Admission

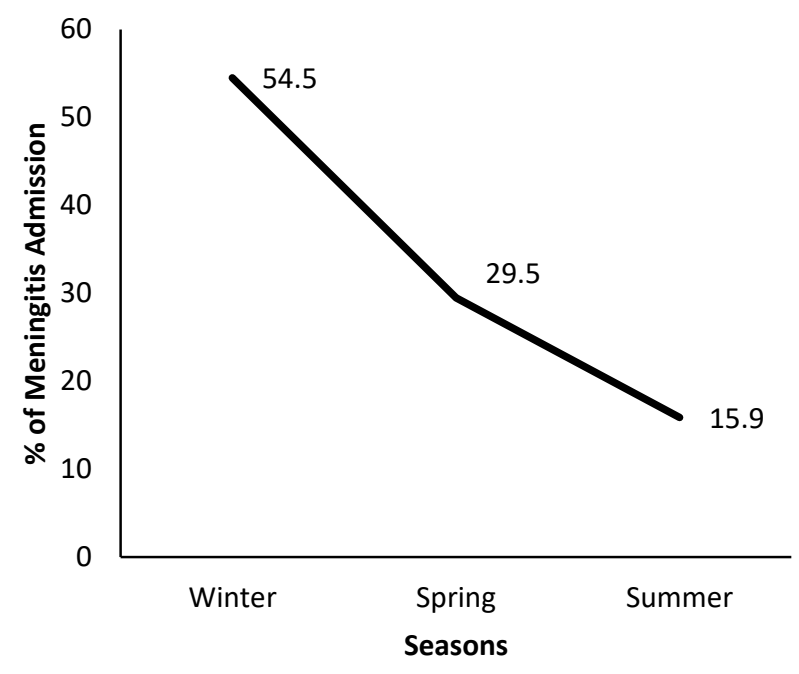

Graph showing Seasonal cluster of hospital admission with suspected meningitis.

Figure 3: Clinical Presentation of Meningitis

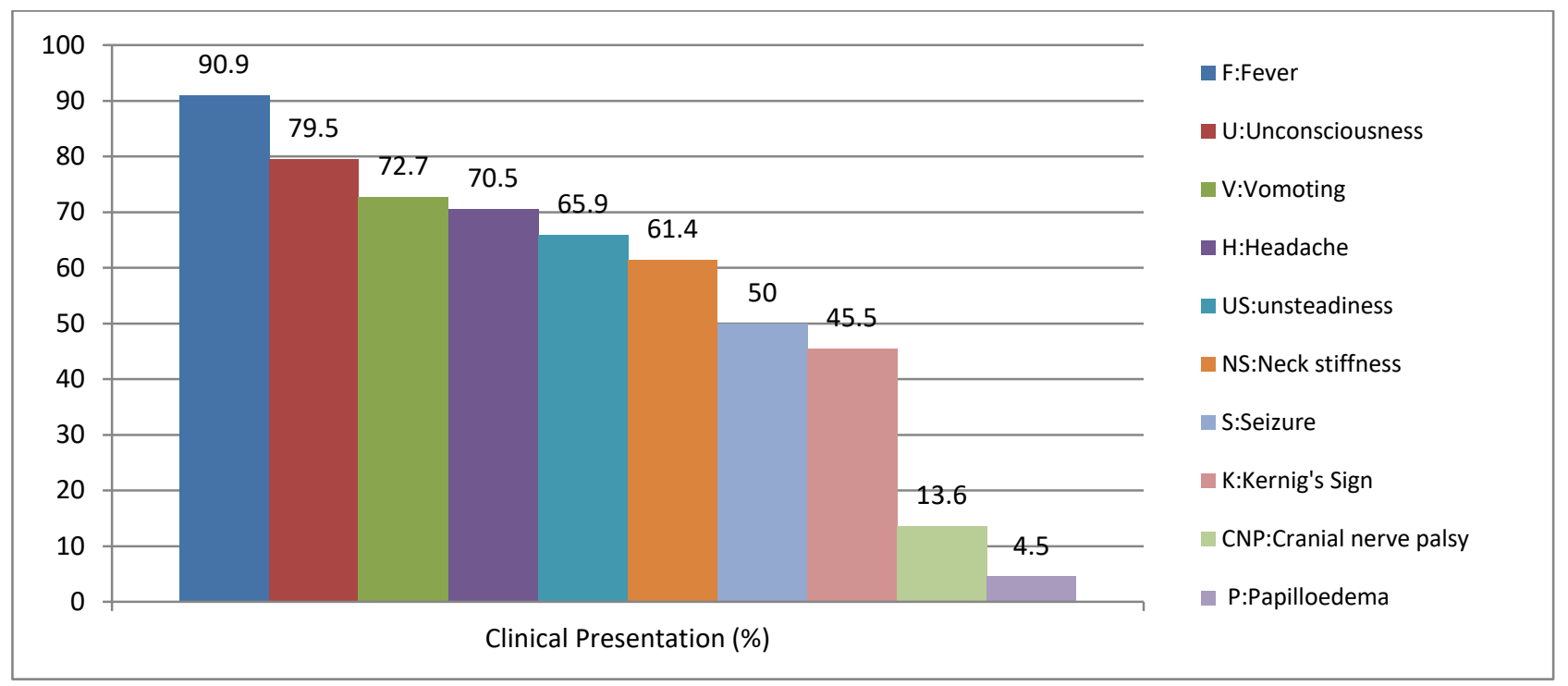

Frequency (\%) of different symptoms of the cohort. F=Fever, U=Unconsciousness, V=Vomiting, $\mathrm{H}=$ Headache, US=Unsteadiness, NS=Neck stiffness, $\mathrm{S}=$ Seizure, $\mathrm{K}=$ Kernig's Sign, $\mathrm{CNP}=$ Cranial nerve palsy, $\mathrm{P}=$ Papilloedema

\section{DISCUSSION}

In this study, we documented risk factors, demographic characteristics, and detailed clinical features of adult meningitis in Kuwait. We also described our experience of managing meningitis patient, with a focus on diagnostic problems and consequent management difficulties within the settings of a referral hospital neurology practice. A diagnosis of meningitis and the type of infection were made largely on the basis of clinical presentation and CSF analysis. Patients presented with the characteristic clinical features of headache, vomiting, fever, stiff neck, and Kernig's sign. Clinical presentation of this cohort was consistent with available literature 2,3 . The finding of papilloedema in a small number of patients $(4.5 \%)$ in our series was similar with reports which maintain that papilloedema is an unusual initial manifestation of meningitis ${ }^{33}$. Seizures were seen in
$50 \%$ of patients which was at variance with the $5 \%-23 \%$ rate reported in other studies 2,3 . Neck stiffness (61.4\%) and Kernig's sign (45.5\%) were present at some stage of the disease. Seventh cranial nerve palsy was the only focal neurological sign seen in $6(13.6 \%)$; while patients with hearing loss and paralysis as described in the literature were not seen in our cohort 2,34 .

Unlike the data of Durand et al where 56\% episodes of community acquired meningitis and $28 \%$ of nosocomial meningitis were 50 years or older, our cohort mainly comprised of younger age group ${ }^{3}$. This is possibly because the population structure of Kuwait is predominantly younger and $67.68 \%$ are $15-49$ years of age 35 . In our cohort male subjects were almost twice the number of females, which also followed Kuwait's population structure 35 . There are reports suggesting gender-based differences in adult 
suffering from meningitis in terms of clinical presentation, laboratory and imaging analysis, and clinical outcomes 36,37; However, our study found no such differences possibly due to small sample size. Seasonal variation and foreign nationality was found to be associated with onset of meningitis in our cohort. Most of the meningitis admissions were in the winter months and bacterial infections accounted for this seasonal increase in winter months. Our finding is in coherence to the previous reports that bacterial meningitis peaks during the winter months 37 . Viral meningitis is reported to be seasonal in temperate regions which occurs usually in the late summer and early fall, while in the tropical and sub-tropical countries it occurs throughout the year without seasonal fluctuations ${ }^{38}$. In our cohort, consistent with this report, viral infection was seen to occur almost in equal frequencies throughout the year. There was no seasonal variation in our cases of TB meningitis as well 39. Majority of the patients (61.4\%) were foreign nationals living in Kuwait and only one thirds of the cases were Kuwaitis nationals (Fig-1). This ethnic composition is probably the result of combination of two factors; many nonKuwaiti patients were either from South Asia and Philippines, or from poor African or Arab countries, many of these countries are endemic for tuberculosis ${ }^{40}$; in both cases being expatriate contract workers, they live in overcrowded accommodations without their families, sometimes exposed to poor hygienic practices. Hence, they were exposed to increased risk of having meningitis.

The causative organism could be identified in only 4 of 44 $(9.1 \%)$ patients with bacterial meningitis. Meningococci and S. agalactiae (Group $\beta$ streptococcus), were seen equally in 2 of the 4 cases with positive bacterial identification. $S$. pnemoniae was positive in 2 patients. S. agalactiae (Group $\beta$ streptococcus), is reported to be seen mostly in women during postpartum period and those with malignancy or on immunosuppression for other conditions ${ }^{41}$. However, our patient with $S$. agalactiae meningitis is a 49 years old, Arab male. He recovered without any residual deficit. In a study of bacterial meningitis reported by Shaltout et al from Kuwait, $H$. influenzae was the predominant organism (45.6\%) with $S$. pneumoniae seen in only half as many patients (22.8\%) ${ }^{34}$. A direct comparison will not be possible since their isolation rate was much higher at $80 \%$ and their study included only children. The low isolation rate in our series may be due to antibiotic treatment by general practitioners prior to admission in our hospital. Literatue review showed an association between antimicrobial activity in the CSF and low positive cultures ${ }^{42}$. However, there are studies that failed to show any significant association between prior antibiotic treatment and negative culture rates ${ }^{43,44}$. These reports also mention that CSF parameters do not change significantly with prior antibiotic treatment. Low positive culture rates and inability to identify the pathogen have been reported by many authors from different regions of the world 45,46. This diagnostic problem continues to hamper initiation of rational therapy in meningitis.

Early antibiotic therapy against the common causative organisms was the mainstay of our management, since we could not isolate the organism in the majority of cases, as previously reported in literature 47 . This empirical approach, perhaps, was responsible for very high complete recovery in our study. Only one patient who had HSV meningitis based on clinical and CSF profiles recovered with residual neurological deficit. It is important to report that this patient was treated only with aciclovir as immediate detection of HSV was possible. Higher rate of neurological deficit $(42.86 \%)$ in TB meningitis in our cohort, may be attributed to delayed presentation to tertiary referral hospital. Our finding is consistent with the recent report of very high morbidity and mortality in this disease 39 .

\section{CONCLUSION}

Several factors such as age, organisms, diagnostic uncertainties, seasonal variations in incidence, community outbreaks etc. contributed to the continuing challenges in meningitis; which required prompt and effective approach in management. We have outlined some of the challenges, we encountered in our practice. While our experience shares many similar features of meningitis from different regions, there are some differences as well. A larger prospective study of meningitis patients seen in our hospital over a 10 year period is underway and it may offer more insight into the patterns of this infection in our region.

Conflict of interest- There was no known conflict of interest.

\section{REFERENCES:}

1. Peltola H. Meningococcal disease: still with us. Rev Infect Dis 1983; 5(1):71-91. https://doi.org/10.1093/clinids/5.1.71

2. Bryndis Sigurdardottir, Olafur Mar Bjornsson, Kristin E Jonsdottir, Helga Erlensdottir, Sigurdur Gudmundsson. Acute bacterial meningitis in Adults: a 20 year overvie. Arch Intern Med; 1997; 157:425-430

https://doi.org/10.1001/archinte.1997.00440250077009

3. Durand ML, Calderwood SB, Weber DJ, Miller SI, Southwick FS, Caviness VS Jr, Swartz MN. Acute bacterial meningitis in adults: a review of 493 episodes. N Engl J Med; 1993; 328:21-28. https://doi.org/10.1056/NEJM199301073280104

4. Chavez-Bueno S, McCracken GH Jr. Bacterial meningitis in children. Pediatr Clin North Am, 2005; 52(3):795-810. https://doi.org/10.1016/j.pcl.2005.02.011

5. Shaltout AA, Auger LT, Awdallah NB, Hijazi Z, Johny M, Hajj KE, Kandil H. Morbidity and mortality of bacterial meningitis in Arab children. J Trop Med Hyg 1989; 92(6): 402-6.

6. van de Beek D., de Gans J, Spanjaard L, Weisfelt M, Reitsma J.B, Vermeulen $\mathrm{M}$, Clinical features and prognostic factors in adults with bacterial meningitis. N Engl J Med, 2004; 351(18):18491859. https://doi.org/10.1056/NEJMoa040845

7. Tikhomirov E, Santamaria M, Esteves K Meningococcal disease: public health burden and control. World Health Stat Q; 1997; 50(3-4):170-177.

8. World Health Organization: Meningococcal meningitis.2011.Available from: http://www.who.int/mediacentre/factsheets/fs141/en/index.h tml

9. World Health Organization: The World Health Report- 2003. Shaping the future. Geneva: WHO.

10. Edmond K, Clark A, Korczak VS, Sanderson C, Griffiths UK, Rudan I. Global and regional risk of disabling sequelae from bacterial meningitis: a systematic review and meta-analysis. Lancet Infect Dis. 2010; 10(5):317-328. https://doi.org/10.1016/S14733099(10)70048-7

11. Renner LA, Newman MJ, Ahadzie L, Antwi-Agyei KO, Eshetu M. Introduction of Haemophilus influenzae type B conjugate vaccine into routine immunization in Ghana and its impact on 
bacterial meningitis in children younger than five years. Pediatr Infect Dis J. 2007; 26(4):356-358.

https://doi.org/10.1097/01.inf.0000258693.19247.8e

12. Martin, M., Casellas, J. M., Madhi, S. A., Urquhart, T. J., Delport, S. D., Ferrero, F. Chamany S, Dayan G. H., Rose C. E., Levine O S, Klugman K P, Feikin, D. Impact of Haemophilus influenzae type b conjugate vaccine in South Africa and Argentina. Pediatr Infect Dis J.2004; 23(9):842-847.

https://doi.org/10.1097/01.inf.0000137575.82874.0c

13. Kuwait Ministry of Health (MOH). A special report of the epidemiological control unit (XL edition). Kuwait City: Ministry of Health, Government of Kuwait. 2003.

14. Zaki M, Daoud AS, ElSaleh Q, West PW. Childhood bacterial meningitis in Kuwait. J Trop Med Hyg.1990; 93(1):7-11.

15. Husain EH, Bahbahani E, Al-Shawaf F, El-Nabi MH, Shafiq MH, AlAteeqi N, Talib AA. Aseptic Meningitis among Children in Kuwait. Med Princ Pract. 2008; 17:122-125. https://doi.org/10.1159/000112965

16. Shabani IS, Al-Ateeqi W, Abu-Shanab O, El-Sori H, Omar N, Ahmed HF, Al-Musallam M. Childhood Meningitis in Kuwait: Epidemiology of Etiologic Agents and the Need for Pneumococcal Disease Prevention. Med Princ Pract. 2006; 15:431-435. https://doi.org/10.1159/000095489

17. Kuwait Government's Meteorology Department. Retrived in March from, http://www.met.gov.kw/Climate/summary.php. 2019.

18. Sigurdardóttir B1, Björnsson OM, Jónsdóttir KE, Erlendsdóttir H, Gudmundsson S. Acute bacterial meningitis in adults: a 20-year overview. Arch Intern Med. 1997; 157:425-30. https://doi.org/10.1001/archinte.1997.00440250077009

19. Thomas KE, Hasbun R, Jekel J, Quagliarello VJ. The diagnostic accuracy of Kernig's sign, Brudzinski's sign, and nuchal rigidity in adults with suspected meningitis. Clin Infect Dis; 2002; 35:4652. https://doi.org/10.1086/340979

20. Phan AD, Benchetrit L, Jacobs FM. Acute bacterial meningitis in adults. Lancet 2017; 22; 389(10079):1609-1610. https://doi.org/10.1016/S0140-6736(17)31020-6

21. Popovic T, Ajello G, Facklam R. WHO laboratory Manual for the diagnosis of Meningitis Caused by Neisseria meningitidis, Streptococcus pneumonia, and Haemophilus influenzae. Geneva: World Health Organisation.1999.

22. Saravolatz LD, Manzor O, VanderVelde N, Pawlak J, Belian B. Broad-range bacterial polymerase chain reaction for early detection of bacterial meningitis. Clin Infect Dis. 2003; 36(1):405. https://doi.org/10.1086/345438

23. Wagdhare S, Kalantri A, Joshi R, Kalantri S. Accuracy of physical signs for detecting meningitis: a hospital-based diagnostic accuracy study. Clin Neurol Neurosurg; 2010; 112: 752-7. https://doi.org/10.1016/j.clineuro.2010.06.003

24. Uchihara T, Tsukagoshi H Jolt accentuation of headache: the most sensitive sign for CSF pleocytosis. Headache; 1991; 31:167-71. https://doi.org/10.1111/j.1526-4610.1991.hed3103167.x

25. Rorabaugh ML, Berlin LE, Rosenberg L. Absence of neurodevelopmental sequelae from aseptic meningitis. Pediatr Res. 1992; 30: 177A.

26. Magnussen CR. Meningitis in adults: ten-year retrospective analysis at a community hospital. N Y State J Med.1980; 80:9016.

27. Behrman RE, Meyers BR, Mendelson M, Sacks HS, Hirschman SZ Central nervous system infections in the elderly. Arch Intern Med.1989; 149:1596-9.

https://doi.org/10.1001/archinte.149.7.1596

28. McKinney RE, Katz SL, Wilfert CM. Chronic enteroviral meningoencephalitis in agammaglobulinemic patients. Rev Infect Dis. 1987; 9:334-56. https://doi.org/10.1093/clinids/9.2.334
29. Marx GE, Chan ED. Tuberculous meningitis: diagnosis and treatment overview. Tuberc Res Treat. 2011; ID:798764. https://doi.org/10.1155/2011/798764

30. de Gans J, van de Beek D. Dexamethasone in adults with bacterial meningitis. N Engl J Med. 2002; 347:1549-56. https://doi.org/10.1056/NEJMoa021334

31. Van de Beek D, de Gans J, Tunkel AR. Community acquired bacterial meningitis in adults. N Engl J Med. 2006; 354:44-53. https://doi.org/10.1056/NEJMra052116

32. Tunkel AR, Sheld WM. Acute bacterial meningitis. Lancet; 1995 ; 346:1675-80. https://doi.org/10.1016/S0140-6736(95)92844-

33. Anderson M. Management of cerebral infection J. Neurol. Neorosurg. Psychiat; 1993; 56:1243-58. https://doi.org/10.1136/jnnp.56.12.1243

34. Statistical report. Gender by Nationality and Age and Governorate. Available from the website of The Public Authority of Civil Information. Kuwait. (http://stat.paci.gov.kw). website retrived from https://www.paci.gov.kw/stat/SubCategory.aspx?ID=2. 2019

35. Dharmarajan L, Salazar L, Hasbun R. Gender differences in community-acquired meningitis in adults: clinical presentations and prognostic factors. J Meningitis. 2016; 1(1):106. https://doi.org/10.4172/2572-2050.1000106

36. Dias, SP, Brouwer MC, Bijlsma MW, van der Ende A, van de Beek D. Sex-based differences in adults with community-acquired bacterial meningitis: a prospective cohort study. Clinical Microbiology and Infection. 2017; 23, 121.e9-121.e15 https://doi.org/10.1016/j.cmi.2016.10.026

37. Paireau, J, Chen A, Broutin H, Grenfell B, Basta NE. Seasonal dynamics of bacterial meningitis: a time-series analysis. The Lancet; 2016; 4: 370-7. https://doi.org/10.1016/S2214109X(16)30064-X

38. Wright WF, Pinto CN, Palisoc K, Baghli S. Viral (aseptic) meningitis: A review. J. Neurol. Sci. 2019; 15(398):176-183 https://doi.org/10.1016/j.jns.2019.01.050

39. Tuberculosis. Fact sheet by World health organisation. Available from https://www.who.int/news-room/factsheets/detail/tuberculosis. 2018.

40. Dunne DW and Quagliarello V Group B Streptococcal Meningitis in Adults. Medicine (Baltimore), 1993; 72(1):1-10. https://doi.org/10.1097/00005792-199301000-00001

41. Kilpatrick ME, Mikhail IA, Girgis NI. Negative cultures of cerebrospinal fluid in partially treated bacterial meningitis Trop Geogr Med. 1987; 39(4):345-9.

42. Mandal BK, The dilemma of partially treated bacterial meningitis. Scand J Infect Dis. 1976; 8(3):185-8. https://doi.org/10.3109/inf.1976.8.issue-3.12

43. Singh M, Paul SS, Gill P. Effect of partial treatment on purulent meningitis. Trop Geogr Med Mar ; 1980; 32(1):16-8.

44. Chotmongkol V, Techoruangwiwat C. Community acquiredbacterial meningitis in adultsSoutheast Asian J Trop Med Public Health. 2000; 31(3):506-8.

45. Hudeckova H, Novakova E, Olear V. Analysis of bacterial meningitis in the Slovak Republic [1991-1998]. Epidemiol Mikrobiol Imunol. 2000; 49(3):130-5.

46. Hussein AS, Shafran SD. Acute bacterial meningitis in adults. A 12-year review. Medicine (Baltimore).2000; 79(6):360-8. https://doi.org/10.1097/00005792-200011000-00002

47. Heckenberg SG, Brouwer MC, van de Beek D. Bacterial meningitis. Handb Clin Neurol. 2014; 121:1361-75. https://doi.org/10.1016/B978-0-7020-4088-7.00093-6 